\title{
How Salt Stress Represses the Biosynthesis of Marrubiin and Disturbs the Antioxidant Activity of Marrubium Vulgare $\mathbf{L}$
}

\section{Marwa Rezgui ${ }^{1 *}$, Nessrine Majdoub ${ }^{1}$, Sofiene Ben-Kaab ${ }^{2}$, Brahim Marzouk ${ }^{3}$, Houda Gouia ${ }^{1}$, Maria Eduarda M. Araújo ${ }^{4}$, Leila Bettaieb Ben-Kaab ${ }^{1}$}

\author{
${ }^{1}$ Faculté des Sciences de Tunis, University Tunis El Manar, 2092 Tunis, Tunisia \\ ${ }^{2}$ Laboratoire des Plantes Aromatiques et Médicinales, Centre de Biotechnologie de Borj-Cedria (CBBC), \\ BP 901, 2050 Hammam-Lif, Tunisia \\ ${ }^{3}$ Laboratoire des Substances Bioactives, Centre de Biotechnologie de Borj-Cedria, \\ 2050, Hammam-Lif, Tunisia \\ ${ }^{4}$ Centro de Química e Bioquímica, Departamento de Química e Bioquímica, Faculdade de Ciências, \\ Universidade de Lisboa, Campo Grande Ed. C8, 1749-016 Lisboa, Portugal
}

Received: 12 June 2016

Accepted: 22 August 2016

\begin{abstract}
We investigated the effects of different concentrations of $\mathrm{NaCl}(25,50,100$, and $150 \mathrm{mM} \mathrm{NaCl})$ on growth, phenolic content, and antioxidant activities of horehound (Marrubium vulgare L.). The long-term salt treatment (up to $100 \mathrm{mM} \mathrm{NaCl}$ ) resulted in significant $(\mathrm{p}<0.05)$ reduction of height, fresh weight, total chlorophyll, and total phenol contents. The negative effect of $\mathrm{NaCl}$ was accompanied by a significant restriction in $\mathrm{K}^{+}, \mathrm{Ca}^{2+}, \mathrm{Fe}^{2+}$, and $\mathrm{Zn}^{2+}$ ion uptake, and by an increase in $\mathrm{Na}^{+}$ion concentrations - the effects of which were most pronounced at the highest $\mathrm{NaCl}$ level. The content of the main bioactive compound marrubiin decreased with increased $\mathrm{NaCl}$ concentrations. The antioxidant activity of the methanol extracts from untreated and salt-treated plants revealed that the extracts from a salt-treated plant with $100 \mathrm{mM}$ exhibits the strongest activity in the DPPH and $\beta$-carotene bleaching assays, while it showed no reducing power. The present results suggest that salt treatment negatively affects the morphological, physiological, and biochemical traits of $M$. vulgare, which appears to be highly sensitive to salinity.
\end{abstract}

Keywords: bioactivity, growth, horehound, phenolic content, salinity

\section{Introduction}

Salinity is one of the environmental factors limiting growth, development, and productivity. The deleterious

*e-mail: mar_warezgui@hotmail.fr

effects of salinity on plant growth are associated with low osmotic potential of soil solution, nutritional imbalance, specific ion toxicity, or a combination of these factors [1]. In addition, salinity induces the generation of reactive oxygen species (ROS) such as the superoxide anions $\left(\mathrm{O}_{2}\right)$, hydrogen peroxide $\left(\mathrm{H}_{2} \mathrm{O}_{2}\right)$, hydroxyl radical $\left({ }^{*} \mathrm{OH}\right)$, and singlet oxygen $\left({ }^{1} \mathrm{O}_{2}\right)$, which can seriously disrupt normal metabolism through oxidative damage to lipids, 
proteins, and nucleic acids [2]. All of these cause adverse pleiotropic effects on plant growth and development at the physiological, biochemical, and molecular levels [3]. The main hallmarks of salt stress are impaired photosynthesis, reduced protein and lipid biosynthesis, and disturbed primary and secondary metabolisms [1].

To cope with salt stress, plants have evolved numerous mechanisms including, among others, the accumulation of compatible solutes (soluble carbohydrates, glycine betaine, polyols, and proline), the induction of enzymatic antioxidants (superoxide dismutase, catalase, peroxidase, ascorbate peroxidase, and glutathione reductase), and the stimulation of non-enzymatic antioxidants ( $\alpha$-tocopherol, $\beta$-carotene, ascorbate, and glutathione) $[2,4]$. Plant responses to salinity have been extensively studied, and in most cases they were focused on general responses such as growth, photosynthesis, plant nutrition, and some biochemical and molecular parameters $[3,5]$. However, little attention has been paid to the effects of salinity on some non-enzymatic antioxidants, namely polyphenols that can play a pivotal role in the mechanism of tolerance/sensitivity of some plant species (particularly medicinal plant species) due to their well-recognized antioxidant activity [6]. The accumulation of phenolics in plant tissues is a distinctive characteristic of plant stress and their induction under different abiotic stress is well documented [7]. This trend is of particular interest due to intriguing biological of phenolic compounds, and any approach leading to overproduction of these valuable compounds - especially in some interesting medicinal plant species - is highly desirable.

Among these medicinal species, horehound (Marrubium vulgare L.) has attracted economic interest, particularly in agriculture. In Spain, it has been popularly used on chicken farms to avoid lice, frequent scratching of animals against it to try worming was observed, which intensified planting on farms [8]. In addition, M.vulgare also provides in important source for the food and pharmaceutical industries, but only in India, where there are 33 registered medicinal formulations containing white horehound [9]. In 2015, M. vulgare preparations were the best-selling herbal dietary supplements, reaching approximately $\$ 106$ million in retail sales [10]. Certainly, $M$. vulgare is one of the highly demanded Mediterranean species for such multiple biological functions as antioxidant, antimicrobial, anti-inflammatory, cholinesterase inhibitory, antigenotoxic, analgesic, anti-diabetic, anti-oedematogenic, anti-hypertensive, hypolipidemic, antispasmodic, hepatoprotective, and vasorelaxant $[9,11-13,15]$. Most of these properties are attributed to their particular phenolic profile and to the furanoid labdane diterpene lactone marrubiin [16]. However, as for other secondary metabolites, the contents of these valuable compounds are likely influenced by abiotic stress [6]. Indeed, salinity can play the role of elicitor for biomolecular production, including polyphenols. Thus, one may hypothesize that optimal polyphenol yield would be obtained using stress-tolerant species [14]. With regard to this topic, on the basis of increasing soil salin- ity in Tunisia and its effect on the survival and productivity of many aromatic crops, a major interest is given in the present contribution to understand the effects of salt stress on growth, marrubiin production, phenolic content and the antioxidant activity of an important industrial and economic plant such as M.vulgare.

\section{Materials and Methods}

\section{Equipment and Reagents}

Ion analyses were acquired by atomic absorption spectrophotometer with an Analyst 300 (Perkin Elmer, Norwalk, USA).

UV-Vis spectra were acquired using a Shimadzu 1603 double-beam spectrophotometer. FTIR analyses were obtained in a Nicolet 6700 spectrometer (Thermo, Italy) using a $\mathrm{KBr}$ disc. $1 \mathrm{HNMR}$ spectra were acquired in a Bruker Avance 400 apparatus at $400 \mathrm{MHZ}$, using chloroform-d as the solvent. All chemicals and reagents were purchased from Sigma-Aldrich and were of analytical grade.

\section{Plant Material and Salt Stress Treatment}

In Tunisia, two varieties of M.vulgare (Typicum Fiori and Lanatum Benth) can be found in all areas except in the extreme south [17]. We chose for study M.vulgare var. Typicum because it is the most common. Seeds of $M$. vulgare were collected from the region of Boussalem in northwestern Tunisia (latitude $36^{\circ} 36^{\prime} 40.03$ ' $\mathrm{N}$, longitude 8 58'11.36”'E, altitude: $141 \mathrm{~m}$ ) in August 2013. This location was characterized by a low annual rainfall of $700 \mathrm{~mm}$ and a mean annual temperature of $16.8^{\circ} \mathrm{C}$. Botanical identification was made by Dr. Mouhiba Ben Nasri-Ayachi, a member of the Botanical Laboratory, Faculty of Science of Tunis, according to the Tunisian flora [17]. The seeds were surface-sterilized in $0.5 \%$ sodium hypochlorite for $10 \mathrm{~min}$, washed thoroughly with distilled water, and then sown manually in $5 \mathrm{~L}$ plastic pots, filled with agricultural soil that had an argyle texture, and maintained under greenhouse conditions. During the pre-treatment, plants were irrigated with distilled water. Forty days after planting, salt treatment was started after obtaining a uniform emergence and establishment of seedlings. Plants were allocated to $\mathrm{NaCl}$ treatment using half-strength Hoagland solution supplied with $0,25,50,100$, and $150 \mathrm{mM} \mathrm{NaCl}$, renewed every three days for five months. Irrigation continued until harvest except for those treated with $150 \mathrm{mM}$, which were completely damaged.

\section{Growth and its Component Parameters}

For each treatment, measurements of plant height and fresh matter weights were evaluated by destructive harvests of three selected plants from each pot. Plants were harvested at the soil surface and immediately weighed (fresh weight, FW). 


\section{Determination of Photosynthetic Pigments}

Total chlorophyll contents in the leaves were determined according to the method of [18]. Fresh tissue from the intervenal leaf area was triturated using mortar-pestle with $80 \%$ acetone. The photosynthetic pigments were extracted at $4^{\circ} \mathrm{C}$ for $24 \mathrm{~h}$ in the dark. To measure the content of chlorophyll a, chlorophyll b, and total chlorophyll, the absorbance of samples was recorded at 662 and $645 \mathrm{~nm}$. The content of photosynthetic pigments was expressed as $\mathrm{mg} \cdot \mathrm{g}^{-1} \mathrm{FW}$.

\section{Determination of Ion Contents}

Ion contents were determined in dried $M$. vulgare samples [19] and essayed by an atomic absorption spectrophotometer with an Analyst 300 (Perkin Elmer, Norwalk, USA).

\section{Extraction, Clean-up, and Fractionation}

To evaluate the antioxidant activity, fresh vegetable material was first extracted with methanol. After removal of the solvent, the residue was washed with petroleum ether to remove pigments and lipids. The resulting residue was re-suspended in methanol, after which it was filtered through a Whatman No. 4 filter paper, concentrated under vacuum, evaporated to dryness, and weighted (methanol extract).

To evaluate the marrubiin content, the plant was first dried to obtain $6 \mathrm{~g}$ of dried material that was extracted with $3 \times 100 \mathrm{~mL}$ acetone. The acetone extracts were combined and evaporated to dryness and extracted with petroleum ether $(15 \mathrm{~mL})$ to obtain the petroleum ether extract. The resulting weight of the acetone extracts were 14.66, 18.92, 37.44 , and $19.23 \mathrm{mg}$ of extract/dry material for the control, $25 \mathrm{mM}, 50 \mathrm{mM}$, and $100 \mathrm{mM}$ of $\mathrm{NaCl}$, respectively.

\section{Isolation and Quantification of Marrubiin}

For marrubiin extraction, $50 \mathrm{~g}$ of dried plant was extracted by percolation with acetone to obtain 18 fractions. Fractions were collected and analyzed by TLC in silica gel plates using cyclohexane-ethyl acetate (6:4). Fractions with the same chromatographic profile were combined to afford five fractions. Fraction $2(1.01 \mathrm{~g})$ was washed with petroleum ether to remove oil and coloring matter to obtain a residue $(0.707 \mathrm{~g})$ that was further fractionated by flash chromatography using an increasing proportion of ethyl acetate in cyclohexane. Fractions containing marrubiin were pooled and crystallized from methanol to afford $131 \mathrm{mg}$ of this diterpene. The identity of marrubiin was confirmed by FTIR and $1 \mathrm{H}$ and 13C NMR. Spectroscopic data was identical to the literature [20]. Quantification was carried out based on a calibration curve performed with known amounts of marrubiin by H1NMR as described by [21]. The intensity of the peak

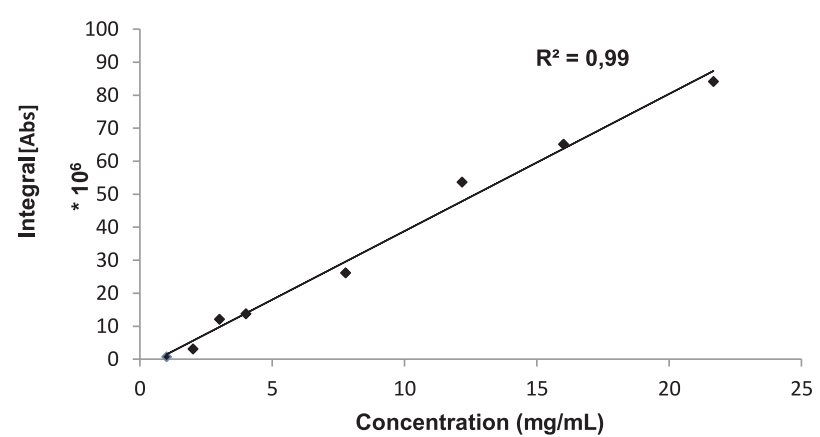

Fig. 1. Calibration curve of marrubiin using the intensity of H-16 at $7.38 \mathrm{ppm}$.

at $7.38 \mathrm{ppm}$ was used to obtain a calibration curve (Fig. 1):

$$
\begin{gathered}
\text { Integral }[\mathrm{Abs}]=4 \cdot 10^{6}[\text { concentration }] \\
-3 \cdot 10^{6}\left(\mathrm{R}^{2}=0.99\right)
\end{gathered}
$$

To quantify the amount of marrubiin, $10 \mathrm{mg}$ of each acetone extract was dissolved in $1 \mathrm{~mL}$ of deuterated chloroform and spectra were recorded in the same conditions.

\section{Determination of Total Phenolic Content}

The total phenolic compound content in the methanol extract was determined by colorimetric assay using the Folin-Ciocalteu reagent [22] and gallic acid as a standard. Briefly, $1 \mathrm{~mL}$ of the methanol solution containing $1 \mathrm{mg}$ of extract was mixed with $4.5 \mathrm{~mL}$ of distilled water. One milliliter of Folin-Ciocalteu reagent was added and the contents of the flask were mixed thoroughly. After $3 \mathrm{~min}, 3 \mathrm{~mL}$ of a $2 \%$ solution of sodium carbonate was added and the mixture was allowed to stand for $2 \mathrm{~h}$ with intermittent shaking. The absorbance (Abs) of the mixture was measured at $760 \mathrm{~nm}$. The concentration of total phenolic compounds in methanol extract was determined as milligram gallic acid equivalents per gram of extract (mg $\mathrm{GAE} / \mathrm{gFW}$ ).

\section{The Fe (III) to Fe (II) Reduction}

The iron (III) reductive capacity of extract, or ascorbic acid, was evaluated as described by [23]. In brief, $1 \mathrm{~mL}$ of dissolved extract with different concentrations was mixed with $2.5 \mathrm{~mL}$ phosphate buffer $(0.2 \mathrm{M}, \mathrm{pH}=6.6)$, and $2.5 \mathrm{~mL}$ of a $10 \mathrm{~g} \cdot \mathrm{L}^{-1}$ potassium hexacyanoferrate $\left[\mathrm{K}_{3}\right.$ $\mathrm{Fe}(\mathrm{CN})_{6}$ ] solution. After $30 \mathrm{~min}$ at $50^{\circ}, 2.5 \mathrm{~mL}$ of a $100 \mathrm{~g} \cdot \mathrm{L}-1$ aqueous trichloroacetic acid (TCA) solution was added and the mixture was stirred with a glass rod. Finally, a $2.5 \mathrm{~mL}$ aliquot was mixed with $2.5 \mathrm{~mL}$ ultrapure water and $0.5 \mathrm{~mL}$ of a $1 \mathrm{~g} \cdot \mathrm{L}^{-1} \mathrm{FeCl}_{3}$ solution and the absorbance of the mixtures (Abs) were recorded at $700 \mathrm{~nm}$. A standard graph using ascorbic acid was obtained and the ability of the extracts to inhibit the reduction of $\mathrm{Fe}(\mathrm{III})$ is expressed as $\mathrm{mg}$ ascorbic acid equivalents per g sample (mg AscAE/g sample). 


\section{Radical Scavenging Assay with DPPH Radical} (DPPH Assay)

The procedure used in the present study was described before [24]. It is based on the reduction of DPPH (2,2-diphenyl-1-picrylhydrazyl) radical in alcoholic solution, in the presence of a hydrogen-donating antioxidant, due to the formation of a non-radical form, DPPH-H. The absorbance decrease was followed spectrophotometrically at $517 \mathrm{~nm}$ and a steady state was reached after 30 minutes. Briefly, an aliquot $(25 \mu \mathrm{L})$ of the extract solution was placed in a stoppered small flask and $2.5 \mathrm{~mL}$ of freshly prepared $0.04 \%$ methanolic solution of DPPH radical was added. The mixture was shaken and maintained at room temperature, in the dark, for $30 \mathrm{~min}$. Controls were prepared at the same temperature and with the same solvent used to prepare the extract solution. The radical scavenging activities of the test samples were expressed as the percentage inhibition of the DPPH radical and calculated according to the following formula:

$$
\mathrm{E}(\%)=[(\text { Acontrol }- \text { Asample }) / \text { Acontrol }] * 100
$$

Acontrol and Asample are the absorbance values of the control and the test samples, respectively. Extract concentration providing 50\% inhibition (EC50) was calculated using regression analysis in MS excel. The assay was performed in triplicate for each extract.

\section{$\beta$-Carotene/Linoleic Acid Assay}

The ability of the extract to inhibit the bleaching of the $\beta$-carotene-linoleic acid emulsion was determined using the method described by [22] with a slight modification. A stock solution was prepared dissolving $\beta$-carotene $(20 \mathrm{mg})$ in chloroform $(10 \mathrm{~mL}) .1 \mathrm{~mL}$ of this solution was mixed with $25 \mu \mathrm{L}$ of linoleic acid and $200 \mathrm{mg}$ of tween 40 into a round-bottomed flask. After removal of chloroform on a rotary evaporator, $50 \mathrm{~mL}$ of oxygenated distilled water was added to the flask with vigorous stirring. Emulsion aliquots $(2.5 \mathrm{~mL})$ were transferred to a series of tubes containing $300 \mu \mathrm{L}$ of methanol extract at a final concentration of $1.6 \mathrm{mg} \cdot \mathrm{mL}^{-1}$ and were further shaken. The mixtures were immediately transferred to the UV cells and placed in a thermostatized UV-Vis unit at $50^{\circ} \mathrm{C}$ and inserted into a Shimadzu 1603 apparatus. The reaction was followed taking readings at regular intervals $(120 \mathrm{~s})$ for a period of $2 \mathrm{~h}$. Two blanks, one containing only water and the other containing the same volume of methanol instead of the extracts, were also prepared. The antioxidant activity (AA) of the extracts was calculated using the following equation:

$$
\begin{gathered}
\mathrm{AA}(\%)=[1-(\mathrm{A}(\mathrm{t}=0)-\mathrm{A}(\mathrm{t}=120) / \\
\mathrm{A} 0(\mathrm{t}=0)-\mathrm{A} 0(\mathrm{t}=120)]^{*} 100
\end{gathered}
$$

...where $\mathrm{AA}$ is the antioxidant activity, $\mathrm{A}(\mathrm{t}=0)$ is the absorbance of the solution in the investigation at $0 \mathrm{~min}$, $A(t=120)$ is the absorbance of the same solution at $\mathrm{t}=120 \mathrm{~min}$, and $\mathrm{A} 0(\mathrm{t}=0)$ and $\mathrm{A} 0(\mathrm{t}=120)$ are the absorbance of the positive control (methanol without extract) sample at $\mathrm{t}=0 \mathrm{~min}$ and $\mathrm{t}=120 \mathrm{~min}$, respectively.

\section{H NMR Estimation of Salt Effect on Fatty Acid Content}

The extract of petroleum ether using NMR spectroscopy was qualitatively investigated to evaluate the salt effect on the fatty acid content and composition according to [25]

\section{Statistical Analysis}

Results were examined statistically using one-way analysis of variance (ANOVA) followed by Duncan's multiple range tests, with different levels of salt treatment as factor, and their interactions were performed for the whole data set using "Statistica v.5.1" software [26]. All determinations were conducted in triplicate. Data are expressed as mean $\pm \mathrm{SD}$. The differences between individual means were considered to be significant at $\mathrm{p}<0.05$.

\section{Results and Discussion}

\section{Visual Symptoms}

With increasing $\mathrm{NaCl}$ concentrations, plant vigor was progressively reduced. Various visual symptoms showing toxicity such as yellowing, necrosis, and stunted growth were observed in NaCl-treated plants (Fig. 2). These symptoms were more evident in the leaves of plants treated with 50 and $100 \mathrm{mM} \mathrm{NaCl}$ with a browning appearance compared to control. Plants treated with $150 \mathrm{mM} \mathrm{NaCl}$ showed signs of severe damages (chlorotic, necrotic, and wilted leaves), as a result of which all parameters (growth, marrubiin content, phenol, and flavonoid contents as well as their antioxidant activities) measurements could not be performed. These observations were consistent with those observed for Salvia officinalis [30], Salvia scalrea [31], and Carthamus tinctorius [32], among others.

\section{Growth and Chlorophyll Content}

As shown in Table 1, a dose-dependent inhibition of growth (estimated in term of fresh weight $\mathrm{FW}$ and height) was noticed in $\mathrm{NaCl}$-treated plants. The inhibition of normal growth of plants was possibly due to alteration in cell division, photosynthesis, leaf area expansion, respiration, primary metabolism, ion imbalance or disturbances in ion homeostasis $[1,33]$. Literature data about the impact of salt stress on the growth of $M$. vulgare are lacking. According to these authors, the reduction in growth may be an adaptive response to stress, suggesteding that the decrease in growth rate under unfavorable conditions allows for the conservation of energy, thereby helping launch appropriate defensive responses and reducing the risk of damage. Given the significant $(\mathrm{p}<0.05)$ reduction 


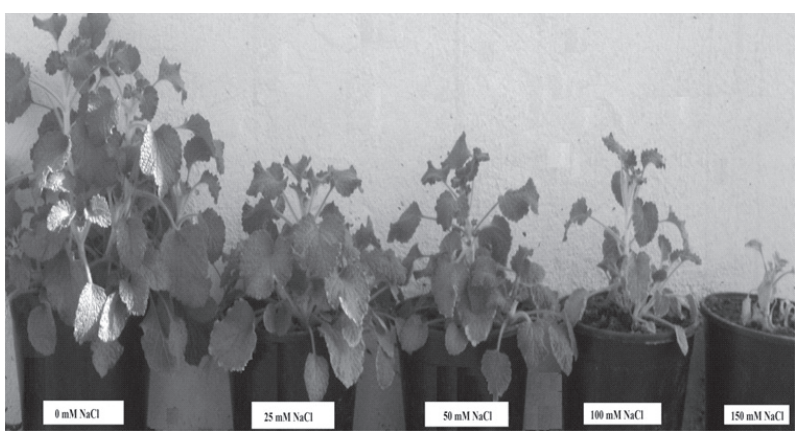

Fig. 2. Effect of salt stress on the growth of $M$. vulgare subjected to different concentrations of $\mathrm{NaCl}(0,25,50,100$, and $150 \mathrm{mM})$ after five months of treatment.

in $\mathrm{FW}$ and height (even at the lowest $\mathrm{NaCl}$ concentration of $25 \mathrm{mM}$ ), it might be concluded that $M$. vulgare is a saltsusceptible species.

Leaf chlorophyll content (chlorophyll a, chlorophyll b, and chlorophyll $\mathrm{a}+\mathrm{b}$ ) is considered an indicator of general plant health. Salt stress-reduced $\mathrm{Chl}$ a and b, resulting in a decrease in total $\mathrm{Chl}$ contents in plants treated with different concentrations of $\mathrm{NaCl}(25,50$, and $100 \mathrm{mM}$, respectively) (Table 1). This behavior has already been observed in Aeceras corniculatum, and the authors have hypothesized that this decrease might possibly be due to the changes in the lipid protein ratio of pigment-protein complexes or increased chlorophyllase activity [29]. The decline in chlorophyll content is believed to be the result of its degradation or inhibition of its biosynthesis under saline conditions [34]. Furthermore, the reduction in chlorophyll content could be due to peroxidation processes in the chloroplast membrane lipids by the reactive oxygen species (ROS) as indicated in previous studies [35]. At this point, it can be speculated that the observed visual symptoms and the reduced growth of $M$. vulgare under saline conditions may be attributed to photosynthesis impairment and the induction of oxidative stress.

\section{Ions Analyses}

We studied the effects of increasing levels of salinity on ion uptake in Marrubium vulgare. Salt treatment significantly reduced the uptake of cat- ionic elements $\mathrm{K}^{+}, \mathrm{Ca}^{2+}, \mathrm{Fe}^{2+}$, and $\mathrm{Zn}^{2+}$ with a dosedependent accumulation of $\mathrm{Na}^{+}$in the aerial part (Table 2). However, a high accumulation of $\mathrm{Na}^{+}$in Marrubium vulgare caused a nutriment unbalance that was at the origin of the depressive effect on plant growth (Fig. 1.) and could result from an antagonistic effect between $\mathrm{Na}^{+}$ in one part and $\mathrm{K}^{+}, \mathrm{Ca}^{2+}, \mathrm{Fe}^{2+}$, and $\mathrm{Zn}^{2+}$ in the other part. In the same way, [36] reported that salinity induced a strong increase of $\mathrm{Na}^{+}$content in NaCl-tolerant cell lines. Consequently, the total charges must be balanced in the cells by the decrease of the others elements. The decline in ion accumulation and their transport selectivity may serve as an important physiological trait of adapting to $\mathrm{NaCl}$ stress, which has been well documented in Ocimum basilicum L. [28], in Solanum lycopersicum [37], Oryza sativa L [38], and Solanum nigrum [39].

\section{Marrubiin Content}

As marrubiin is the major constituent of $M$. vulgare, and the active principle responsible for the medicinal properties of the plant, the effect of salt stress on the production of this compound was investigated.

The identity of isolated marrubiin was confirmed by FTIR, ${ }^{1} \mathrm{H}$, and ${ }^{13} \mathrm{C}$ NMR [20]. Analysis of proton spectra (Fig. 3) showed three well-separated peaks at 6.29, 7.25, and $7.38 \mathrm{ppm}$, corresponding to protons $\mathrm{H}-15, \mathrm{H}-14$, and $\mathrm{H}-16$, respectively. The intensity of the peak at $7.38 \mathrm{ppm}$ was used to quantify the amount of marrubiin in the acetone extracts of dry materials.

Marrubiin content decreased gradually with increased $\mathrm{NaCl}$ concentrations. The averaged values were 1.38, $0.93,0.62$, and $0.34 \mathrm{mg} / \mathrm{g}$ DW for concentrations of 0,25 , 50 , and $100 \mathrm{mM} \mathrm{NaCl}$, respectively. The obtained values of detected marrubiin in different samples were relatively low. We can explain this by the old age of harvested plants (five months). However, the accumulation of furanic labdane diterpenes was previously investigated in plantlets of $M$. vulgare during the first three months following germination in order to get information on the time when accumulation starts; the authors concluded that the accumulation of furanic labdane diterpenes in older leaves was rather low. The amount of marrubiin found in leaves of 12-week-old plantlets of M.vulgare was $200 \mu \mathrm{g} / \mathrm{FW}$ [40]. As a conclusion, the quantitative variation of marrubiin

Table 1. Variation of fresh weight (FW), height, chlorophyll (a), chlorophyll (b) and total chlorophyll content of plants subjected to water with different $\mathrm{NaCl}$ concentrations $(0,25,50,100 \mathrm{mM})$ during 5 months.

\begin{tabular}{|c|c|c|c|c|c|}
\hline $\begin{array}{c}\mathrm{NaCl} \\
(\mathrm{mM})\end{array}$ & $\begin{array}{c}\text { Fresh weight } \\
(\mathrm{g})\end{array}$ & $\begin{array}{c}\text { Height } \\
(\mathrm{cm})\end{array}$ & $\begin{array}{c}\text { Chlorophyll (a) } \\
(\mathrm{mg} / \mathrm{gFW})\end{array}$ & $\begin{array}{c}\text { Chlorophyll (b) } \\
(\mathrm{mg} / \mathrm{gFW})\end{array}$ & $\begin{array}{c}\text { Total chlorophyll } \\
(\mathrm{mg} / \mathrm{gFW})\end{array}$ \\
\hline 0 & $236.24 \pm 6.26^{\mathrm{a}}$ & $39 \pm 4.58^{\mathrm{a}}$ & $1.00 \pm 0.03^{\mathrm{a}}$ & $0.41 \pm 0.01^{\mathrm{a}}$ & $1.42 \pm 0.02^{\mathrm{a}}$ \\
\hline 25 & $115.72 \pm 4.12^{\mathrm{b}}$ & $28 \pm 2.51^{\mathrm{b}}$ & $0.63 \pm 0.01^{\mathrm{b}}$ & $0.34 \pm 0.00^{\mathrm{b}}$ & $0.98 \pm 0.01^{\mathrm{b}}$ \\
\hline 50 & $95.17 \pm 1.97^{\mathrm{c}}$ & $25 \pm 7.51^{\mathrm{b}}$ & $0.85 \pm 0.02^{\mathrm{b}}$ & $0.35 \pm 0.00^{\mathrm{b}}$ & $1.19 \pm 0.02^{\mathrm{b}}$ \\
\hline 100 & $20.85 \pm 2.07^{\mathrm{d}}$ & $9 \pm 5.29^{\mathrm{c}}$ & $0.41 \pm 0.00^{\mathrm{c}}$ & $0.08 \pm 0.01^{\mathrm{c}}$ & $0.49 \pm 0.03^{\mathrm{c}}$ \\
\hline
\end{tabular}

Averages \pm standard deviation were obtained from three different experiments. Data with the same letter are not different according to ANOVA (analysis of variance) $(\mathrm{p}<0.05)$. The results are sorted in decreasing order: $\mathrm{a}>\mathrm{b}>\mathrm{c}>\mathrm{d}$. 
Table 2. Variation of $\mathrm{Na}^{+}, \mathrm{K}^{+}, \mathrm{Ca}^{2+}, \mathrm{Fe}^{2+}, \mathrm{Zn}^{2+}$ contents $(\mu \mathrm{g} / \mathrm{g} \mathrm{DW})$ of $M$. vulgare subjected to different $\mathrm{NaCl}$ concentrations $(0,25,50$ and $100 \mathrm{mM}$ ) during 5 months.

\begin{tabular}{|c|c|c|c|c|c|}
\hline Treatment $(\mathrm{NaCl})$ & $\mathrm{Na}+$ & $\mathrm{K}^{+}$ & $\mathrm{Ca}^{2+}$ & $\mathrm{Fe}^{2+}$ & $\mathrm{Zn}^{2+}$ \\
\hline $0 \mathrm{mM}$ & $1230 \pm 10^{\mathrm{c}}$ & $28700 \pm 290^{\mathrm{a}}$ & $22600 \pm 670^{\mathrm{a}}$ & $690 \pm 10^{\mathrm{a}}$ & $70 \pm 3^{\mathrm{a}}$ \\
\hline $25 \mathrm{mM}$ & $2130 \pm 30^{\mathrm{c}}$ & $27400 \pm 120^{\mathrm{a}}$ & $20900 \pm 20^{\mathrm{b}}$ & $530 \pm 10^{\mathrm{b}}$ & $50 \pm 3^{\mathrm{b}}$ \\
\hline $50 \mathrm{mM}$ & $6160 \pm 490^{\mathrm{b}}$ & $23130 \pm 20^{\mathrm{ab}}$ & $19700 \pm 40^{\mathrm{c}}$ & $460 \pm 30^{\mathrm{bc}}$ & $40 \pm 5^{\mathrm{c}}$ \\
\hline $100 \mathrm{mM}$ & $16230 \pm 220^{\mathrm{a}}$ & $17630 \pm 580^{\mathrm{b}}$ & $17900 \pm 50^{\mathrm{d}}$ & $370 \pm 40^{\mathrm{c}}$ & $40 \pm 5^{\mathrm{c}}$ \\
\hline
\end{tabular}

Averages \pm standard deviation were obtained from three replicates. Data with the same letter are not different according to ANOVA (analysis of variance) $(\mathrm{p}<0.05)$; DW, Dry weight.

content can be attributed to several factors, e.g., seasons, environment, genes, varieties, origin, methods of extraction, and plant part.

In our present work, the results suggest that the synthesis/accumulation of marrubiin in $M$. vulgare is particularly sensible to salt stress.

The decline of diterpenes content in response to salinity has been previously reported in clary sage (Salvia scalrea), where a significant decrease of manoyl oxide and phytol was observed in hydroponic culture containing 25, 50, and $75 \mathrm{mM} \mathrm{NaCl}$ [41]. In our case, it seems that the reduction in marrubiin content is likely due to the inhibition of its correspondent biosynthesis enzymes, namely diterpenes synthases [41] in response to salinity. Another possible explanation is that the decline of marrubiin could be linked with the accelerated senescence induced by salt stress as reported in Cistus creticus [43]. By using transcriptomic analysis, these authors have successfully proved that young leaves accumulated more labdane-diterpenes than older leaves, and such a trend is highly influenced by abiotic stress [44].

\section{Total Phenolic Content}

Compared with the control, salt-treated plants exhibit lower values of TPC. According to the literature, the effect of salinity on TPC has been found to depend on the species and the stress intensity, our results are in conformity with the study about Nigella sativa, salt treatment was found to affect phenol content, which decreased by 30,54 , and $61 \%$ in response to 20,40 , and $60 \mathrm{mM} \mathrm{NaCl}$ [6]. An earlier study showed that the exposure of Coriandrum sativum causes a significant decrease in polyphenol accumulation occurring in about $37 \%, 43 \%$, and $66 \%$, respectively, at 25,50 , and $75 \mathrm{mM}$, with respect to the control $\mathrm{NaCl}$ [44]. These author's reports concluded the salt sensitivity of studied plants. According to [31], the drastic effect of salinity $(75 \mathrm{mM})$ on TPC of Salvia sclarea L. may be due to a less efficient ROS as a result of an imbalance between ROS and antioxidant formation, leading to the installation of the oxidative stress. However, this trend is contradictory to that observed in cucumber [46], Carthamus tinctorius [47, 48], Salvia officinalis [30], and Origanum majorana
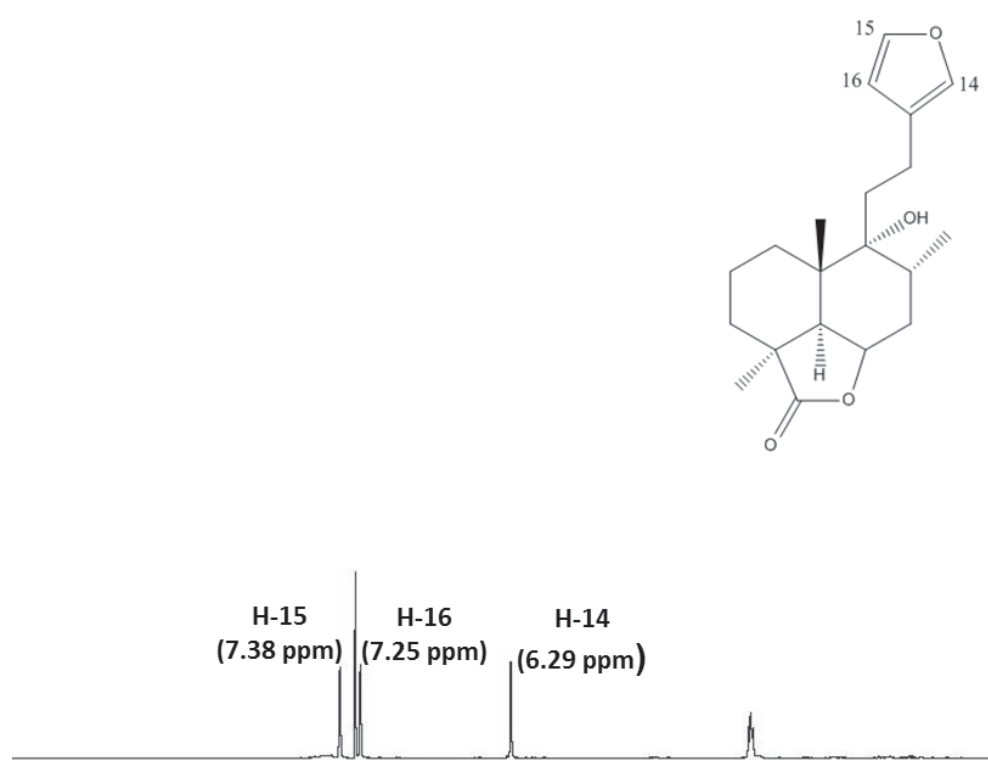

ppm)

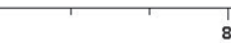

$8 \quad 1$

64

Fig. 3. ${ }^{1} \mathrm{H}-\mathrm{NMR}$ spectra of marrubiin. 
Table 3. Variation of methanol extract weight (EW, $\mathrm{mg} / \mathrm{gFW}$ ), total phenolic content (TPC, $\mathrm{mg} \mathrm{GAE} / \mathrm{gFW}$ ) and antioxidant activity of $M$. vulgare subjected to different $\mathrm{NaCl}$ concentrations $(0,25,50$ and $100 \mathrm{mM})$ during 5 months. Antioxidant activity was evaluated by the reducing power assay, the DPPH test and bleaching of beta carotene assay.

\begin{tabular}{|c|c|c|c|c|c|}
\hline $\begin{array}{c}\text { Salinity } \\
(\mathrm{NaCl}, \mathrm{mM})\end{array}$ & $\begin{array}{l}\text { Methanol extract } \\
(\mathrm{mg} / \mathrm{g} \mathrm{FW})\end{array}$ & $\begin{array}{c}\text { TPC } \\
(\mathrm{mg} \mathrm{GAE} / \mathrm{gFW}) \\
\end{array}$ & $\begin{array}{l}\text { Reducing power } \mathrm{Fe}^{3+} / \mathrm{Fe}^{2+} \\
(\mathrm{mg} \text { Asc AE/gEW) }\end{array}$ & $\begin{array}{l}\text { DPPH scavenging } \\
\left(\mathrm{EC}_{50} \mu \mathrm{g} / \mathrm{mL}\right)\end{array}$ & $\begin{array}{l}\text { Bleaching of beta } \\
\text { carotene }(\%) *\end{array}$ \\
\hline 0 & 41.9 & $3.7 \pm 0.01^{\mathrm{a}}$ & $96.89 \pm 3.24^{\mathrm{a}}$ & $499.58 \pm 2.45^{\mathrm{c}}$ & n.a. \\
\hline 25 & 46.9 & $2.1 \pm 0.03^{b}$ & $3.05 \pm 0.40^{\mathrm{c}}$ & $807.38 \pm 8.33^{b}$ & 15.92 \\
\hline 50 & 14.9 & $0.8 \pm 0.00^{\mathrm{b}}$ & $58.95 \pm 0.23^{b}$ & $857.26 \pm 0.22^{\mathrm{a}}$ & 27.51 \\
\hline 100 & 22.8 & $1.2 \pm 0.00^{\mathrm{b}}$ & n.a & $199.86 \pm 13.1^{\mathrm{d}}$ & 40.42 \\
\hline
\end{tabular}

Averages \pm standard deviation were obtained from three different experiments. Data with the same letter are not different according to ANOVA (analysis of variance) $(\mathrm{p}<0.05)$. n.a : no activity $(\leq 5 \%)$; FW, Fresh weight; GAE, gallic acid equivalents; EW, Extract weight; Asc AE equivalents, mg ascorbic acid/g sample.

*concentration tested: $1.6 \mathrm{mg} \cdot \mathrm{mL}^{-1}$.

[49]. In the present study, the decrease in TPC could be ascribed to decreased activity of phenylalanine ammonia lyase (PAL: the first enzyme of the phenylpropanoid pathway that catalyzes the elimination of $\mathrm{NH}_{3}$ from L-phenylalanine to produce trans-cinnamate) probably due to the accumulation of toxic levels of $\mathrm{Na}^{+}$and $\mathrm{Cl}^{-}$. Supporting information is provided by [45], who reported that decreased phenol accumulation was associated with lower PAL activity in wheat. The susceptibility of the phenylpropanoid metabolism to salinity justifies our previous conclusion about the sensitivity of $M$. vulgare to salt stress.

To test whether the changes in TPC content could influence the antioxidant capacity of $M$. vulgare extracts, three complementary assays were performed.

\section{Antioxidant Activity}

Data depicted in Table 3 show that all methanol extracts have the capacity to scavenge the DPPH radical. The most active extracts was those derived from plants treated with $100 \mathrm{mM} \mathrm{NaCl}\left(\mathrm{EC}_{50}=199.86 \pm 13.1 \mu \mathrm{g} / \mathrm{mL}\right)$, followed by those issued from untreated samples $\left(\mathrm{EC}_{50}\right.$ $=499.58 \pm 2.45 \mu \mathrm{g} / \mathrm{mL}$ ). Salt-treated plants with 25 and $50 \mathrm{mM} \mathrm{NaCl}$ showed the lowest activity with an $\mathrm{EC}_{50}$ of $807.38 \pm 8.33$ and $857.26 \pm 0.22 \mu \mathrm{g} / \mathrm{mL}$, respectively. These data clearly show that the radical-scavenging activity of methanol extract was not directly linked to the TPC content. The equivocal correlation between the TPC and antioxidant activity can be explained in several ways: In fact, the TPC fraction does not necessarily incorporate all the antioxidants. The synergistic interactions between antioxidants in the extract make the antioxidant power not only dependent on the concentration but also in the structure and the nature of antioxidants. Besides, the antioxidant process is very complex, depending on several modes of polyphenol interaction that can participate to different degrees because of their different ratio among single classes or subclasses [50]. Indeed, in the report of [51], who tested the antioxidant activity of individual phenolic compounds, flavan-3-ols possessed the highest radical scavenging activity while the mechanism of antioxidant activity depended on specific structures, e.g., the number of hydroxyl groups and the presence of the $-\mathrm{CH}=\mathrm{CH}-\mathrm{COOH}$ group. Therefore, The high anti-radical activity observed in plants treated with $100 \mathrm{mM}$ was presumably also due to the implication of antioxidant enzymes (i.e., SOD, CAT, POD, and APX) as well as antioxidant metabolites (i.e., such ascorbic acid, reduced glutathione, carotenoids, tocopherols, alkaloids, and non-protein amino acids [52] or to particular phenolic compounds induced by salt treatment. The decrease in the DPPH-radical scavenging effect was similar to that observed in Coriandrum staivum [44]. Thus, it has been found under saline conditions that the scavenging activity was strongly diminished, the IC50 values increased by $116 \%, 129 \%$, and $188 \%$, respectively, at 25,50 , and $75 \mathrm{mM} \mathrm{NaCl}$ in comparison to the control. The authors suggest that an imbalance between reactive oxygen species (ROS) generation and scavenging systems might have occurred in Coriandrum staivum under salt treatment.

We also evaluated the reducing power of methanol extract (Table 3). As shown, the methanol extracts from untreated plants present the highest reducing power and that effect decreased with increasing salinity. The decrease in the reducing power of the extract can probably be due to the decrease in the phenol content (Table 3). However, there are some drawbacks regarding this test since it is assumed that all antioxidant compounds (reductants) able to produce the $\mathrm{Fe}(\mathrm{III}) / \mathrm{Fe}$ (II) complex are also able to reduce ROS and NOS (reactive nitrogen species). This statement is true for ascorbic acid and many phenols, but it does not apply to all compounds, such as, for example, gluthatione - an important antioxidant in vivo but unable to efficiently reduce $\mathrm{Fe}(\mathrm{III})$.

By using the $\beta$-carotene/linoleic acid model system, only extracts from salt-treated plants were found to be active (Table 3; Fig. 4). Plants treated with $100 \mathrm{mM}$ $\mathrm{NaCl}$ present the highest activity $(40.42 \%)$, followed by treatment with $50(27.51 \%)$ and $25 \mathrm{mM} \mathrm{NaCl}(15.92 \%)$.

The strong antioxidant activity observed in plants treated with $100 \mathrm{mM} \mathrm{NaCl}$ might be due to factors other than the amount of phenolic compounds [53]. These authors reported a significant correlation between the total 


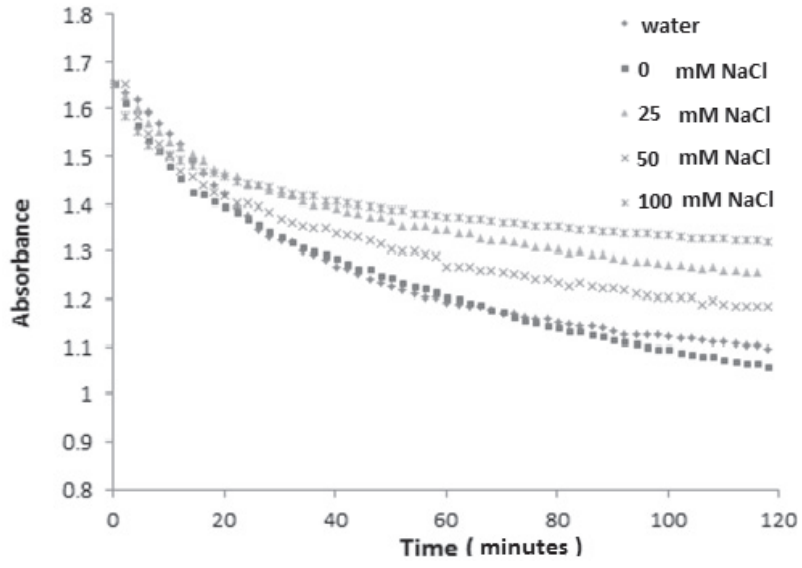

Fig. 4. Kinetic behavior of $\beta$-carotene bleaching of methanolic extract from M.vulgare at $1.6 \mathrm{mg} \cdot \mathrm{mL}^{-1}$.

Averages \pm standard deviation were obtained from three different experiments. Data with the same letter are not different according to ANOVA (analysis of variance) $(\mathrm{p}<0.05)$. n.a: no activity $(\leq 5 \%)$; EW, extract weight; GAE, gallic acid equivalents; Asc AE equivalents, mg ascorbic acid/g sample.

*concentration tested: $1.6 \mathrm{mg} . \mathrm{mL}^{-1}$

phenolic and antioxidant capacities for flaxseed and cereals, but not for the anthocyanin-rich materials and medicinal plants, which is similar to our results. Besides, another interesting phenomenon called the "polar paradox" has been reported [54]. It is observed that lipophilic antioxidants are more effective in oil-in-water emulsion systems than in bulk oil, while the hydrophilic antioxidants are more effective in bulk oil systems. This behaviour is explained by the stronger affinity of the non-polar antioxidants to the oil-water interface of the emulsion and the high affinity of the polar antioxidants to the air-oil interface. As a result, non-polar antioxidants concentrate in the interface of the oil droplets, ensuring high protection of the emulsion itself and, on the other hand, polar antioxidants remaining dissolved in the aqueous phase are more diluted and hence less effective. This phenomenon can explain the increased antioxidant activity evaluated by this test that is opposite to the evaluation of total phenol content.

To test the presence of lipophilic compounds, the petroleum ether extracts were analyzed by ${ }^{1} \mathrm{HNMR}$.

\section{${ }^{1}$ HNMR Estimation of Fatty Acid Content and Composition}

${ }^{1} \mathrm{HNMR}$ spectra of petroleum ether extract of $M$. vulgare was investigated in the region of $5.8 \mathrm{ppm}$ to $0.5 \mathrm{ppm}$ (Fig. $5)$. These spectra are very complex since they correspond to a mixture of lipid compounds. However, some information can be obtained from the careful investigation of these spectra. According to [25], a multiplet at 5.40 and $5.26 \mathrm{ppm}$ observed in the spectra of oils can be assigned to the hydrogen atoms linked to the double bonds of acyl groups of glycerides, and in the region 5.26 and $5.20 \mathrm{ppm}$ to the proton linked to carbon 2 of glycerol of a glyceryl

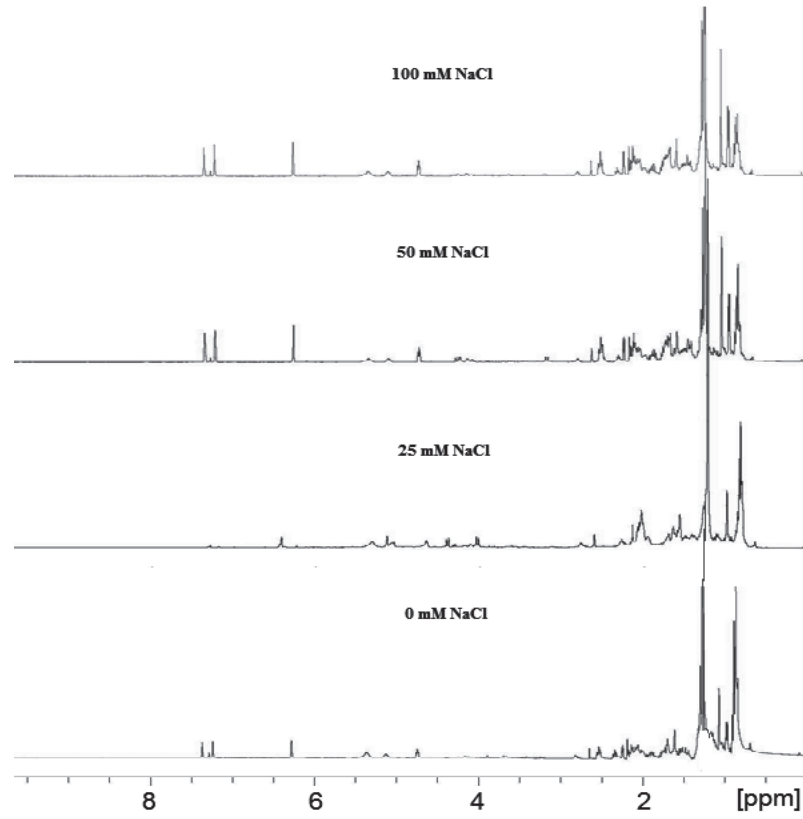

Fig. 5. ${ }^{1} \mathrm{H}-\mathrm{NMR}$ spectra of petroleum ether extracts of M.vulgare subjected to different concentrations of $\mathrm{NaCl}(0,25,50$, and $100 \mathrm{mM}$ ) after five months of treatment.

group. In the spectra of the petroleum ether extracts these two peaks had merged in a multiplet. The center of this multiplet moved from 5.31 to $5.37 \mathrm{ppm}$ with increasing salt stress, which can be explained by the disappearance of triglycerides and the appearance of increasing amounts of free fatty acids.

Additional confirmation was obtained by a similar decrease of the intensity of the multiplet at 4.32 and $4.10 \mathrm{ppm}$, corresponding to the methylene of glycerol in triglycerides. In fact, the reduced intensity of this peak when salinity increases indicates that the ester function disappears. This information was further confirmed by a similar change at $2.38 \mathrm{ppm}$ and $2.27 \mathrm{ppm}$, corresponding to the alpha-methylene to the carboxylate of the ester or of the free fatty acid. According to [21], there is a small difference between these protons, namely that those from the ester produce a triplet at a higher field (lower ppm) than those from free fatty acids. The spectra of a mixture of triglycerides and free fatty acids show a multiplet corresponding to the superposition of these peaks. In the observed spectra the intensity of the signal at 2.27 ppm moves respectively to $2.31,2.33$, and $2.34 \mathrm{ppm}$ with increasing salinity, which in our opinion is due to increasing amounts of free fatty acids in the extract.

Regarding the composition of the acyl groups, a ratio between the intensity of the methylene protons at $2.27 \mathrm{ppm}$ present in all acyl groups, and those at 2.83 ppm belonging only to the polyunsaturated ones [25] can be established. This ratio is similar in the control and the plants treated with $25 \mathrm{mM}$ and $50 \mathrm{mM} \mathrm{NaCl}$, indicating that apparently there is no appreciable change in fatty acid composition. However, at the highest dose of salt, $\mathrm{NaCl} 100 \mathrm{mM}$, the 
presence of unsaturated acids dramatically decreases, indicating a desperate effort of the plant to maintain its integrity [55].

\section{Conclusions}

As a final conclusion it can be said that salt stress decreases growth and biomass of $M$. vulgare L. areal parts as well as total phenolic content. Furthermore, environmental stresses can significantly enhance some antioxidant properties such as radical scavenging capacity and inhibition of lipid peroxidation.

Therefore, in our experiment we thought that the increase of antioxidant activities under saline conditions may contribute to the ability of the plant to survive in adverse environmental stress as salinity.

The production of marrubiin, the main bioactive compound extracted from $M$. vulgare, is greatly affected by salinity. The increase in salt concentration to $25 \mathrm{mM}$ has the consequence of lowering the production of marrubiin by about $23 \%$. Doubling the $\mathrm{NaCl}$ concentration to 50 $\mathrm{mM}$, we observed an important decrease of this important bioactive compound content of about $50 \%$ of the control plants.

This information can be useful for pharmaceutical companies interested in farming $M$. vulgare as a phytomedicine or local healers, since this environmental stress will affect the medicinal properties of the plant. Nevertheless, taking into account this information, $M$. vulgare can be an accessible fragrances in flavoring additives and beverages. Therefore, further investigation can be important to know the development of new chemotypes at different salt levels, which could be considered as a valuable source for functional foods, nutraceuticals, cosmetics, and pharmaceutical industries.

\section{Acknowledgements}

The work of Maria Eduarda M. Araújo was funded by Fundação para a Ciência e a Tecnologia (FCT), Portugal (PEst-OE/QUI UI0612/2013). The authors thank Dr. Karim Hosni from Laboratoire des Substances Naturelles, Institut National de Recherche et d'Analyse Physicochimique (INRAP), Sidi Thabet, 2020 Ariana, Tunisia, for English language corrections and a critical reading of this article. The authors are grateful to Dr. Mouhiba Ben Nasri-Ayachi for plant identification. The authors thank Dr Salwa Rejeb from Laboratoire de Physiologie Végétale de l'INRGREF, Tunisia, for the mineral analysis.

\section{References}

1. PARIDA A.K., DAS A.B. Salt tolerance and salinity effects on plants: a review. Ecotoxicol. Environ. Saf. 60, 324, 2005.
2. DANESHMAND F., ARVIN M.J., KALANTARI K.M. Physiological responses to $\mathrm{NaCl}$ stress in three wild species of potato in vitro. Acta Physiol Plant. 32 (1), 91, 2010.

3. HARRATHI J., HOSNI K., KARRAY-BOURAOUI N., ATTIA H., MARZOUK B., MAGNE C., LACHÂAL M. Effect of salt stress on growth fatty acids and essential oils in safflower (Carthamus tinctorius L.). Acta Physiol Plant. 34, 129, 2012.

4. LI G.,WAN S., ZHOU J., YANG Z., QIN P. Leaf chlorophyll fluorescence, hyperspectral reflectance, pigments content, malondialdehyde and proline accumulation responses of castor bean (Ricinus communis L.) seedlings to salt stress levels. Ind Crops. 31 (1), 13, 2010.

5. QURESHI M.K., SUJEETH N., GECHEV T.S., HILLE J. The zinc finger protein ZAT11 modulates paraquat-induced programmed cell death in Arabidopsis thaliana. Acta Physiol Plant. 35, 1863, 2013.

6. BOURGOU S., BETTAIEB I., SAIDANI M., MARZOUK B. Fatty Acids, Essential Oil, and Phenolics Modifications of Black Cumin Fruit under $\mathrm{NaCl}$ Stress Conditions. J. Agric. Food Chem. 58, 12399, 2010.

7. PRADO K., MAUREL C. Regulation of leaf hydraulics: from molecular to whole plant levels. Front Plant Sci. 4, 255, 2013.

8. RODRÍGUEZ J.V., MARTÍN J.E. REVIEW An Insight into a Blockbuster Phytomedicine; Marrubium vulgare L. Herb. More of a Myth than a Reality? Phytother. Res. 2016.

9. AKTHER N., SHAWL A.S., SULTANA S., CHANDAN B.K., AKHTER M. Hepatoprotective activity of Marrubium vulgare against paracetamol induced toxicity. J Pharm Res. 7 (7), 565, 2013.

10. IZZO A.A., HOON-KIM S., RADHAKRISHNAN R., WILLIAMSON E.M. A critical approach to evaluating clinical efficacy, adverse events and drug interactions of herbal remedies. Phytother Res. 30 (5), 691, 2016.

11. ORHAN E.I., BELHATTAB R., ŞENOL F.S., GÜLPINAR A.R., HOŞBAŞ S., KARTAL M. Profiling of cholinesterase inhibitory and antioxidant activities of Artemisia absinthium, A. Herba-alba, A. fragrans, Marrubium vulgare, M. astranicum, Origanum vulgare subsp. glandulosum and essential oil analysis of two Artemisia species. Ind Crops Prod. 32, 566, 2010.

12. ZAABAT N., HAY A., MICHALET S., DARBOUR N., BAYET C., SKANDRANI I., CHEKIR-GHEDIRA L., AKKAL S., DIJOUX-FRANCA M. Antioxidant and antigenotoxic properties of compounds isolated from Marrubium deserti de Noé. Food Chem. Toxicol. 49 (12), 3328, 2011.

13. BOUDJELAL A., HENCHIRI C., SIRACUSA L., SARI M., RUBERTO G. Compositional analysis and in vivo anti-diabetic activity of wild Algerian Marrubium vulgare L. infusion. Fitoterapia. 83 (2), 286, 2012.

14. De Abreu, I.N., Mazzafera, P. Effect of water and temperature stress on the content of active constituents of Hypericum brasilienne Choisy. Plant Physiol Biochem. 43, $241,2005$.

15. BOULILAA A., SANAAB A., BEN SALEM I., ROKBENI N., M'RABET Y., HOSNI K., FERNANDEZ X. Antioxidant properties and phenolic variation in wild populations of Marrubium vulgare L. (Lamiaceae). Ind Crops Prod. 76, 616, 2015.

16. POPOOLA O.K., ELBAGORY A.M., AMEER F., HUSSEIN A.A. A review: Marrubiin. Molecules. 18, 9049, 2013.

17. ALAPETITE P.G. Flore de la Tunisie. Angiospermes-Dicotylédones Gamopétales. Imprimerie Officielle de la République Tunisienne. Tunis, 581, 1988. 
18. LICHTENTHALER H.K., BUSCHMANN C. Chlorophylls and Carotenoids: Measurement and Characterization by UVVIS Spectroscopy. Curr Prot Food Anal Chem.431, 2001.

19. LARSSON H.E., BORNMAN J.F., HÅKAN A.S.P. Influence of UV-B radiation and $\mathrm{Cd} 2+$ on chlorophyll fluorescence, growth and nutrient content in Brassica napus. J. Exp. Bot. 49, 1031, 1998.

20. ARGYROPOULOU C., KARIOTI A., SKALTSA H. Labdane diterpenes from Marrubium thessalum. Phytochemistry. 70, 635, 2009.

21. PIRES J., PRASIL B., ARAÚJO M.E.M. reduction of free fatty acids in acidic nonedible oils by modifeid K10 clay. $\mathrm{J}$ Am Oil Chem Soc. 90 (4), 555, 2013.

22. AMESSIS-OUCHEMOUKH N., MADANI K., FALÉ L.V.P., SERRALHEIRO M.L., ARAÚJO M.E.M. Antioxidant capacity and phenolic contents of some Mediterranean medicinal plants and their potential role in the inhibition of cyclooxygenase-1and acetylcholinesterase activities. Ind Crops Prod. 53, 6, 2014a.

23. OYAIZU M. Studies on products of browning reactions: Antioxidative activities of browning products of browning reaction prepared from glucosamine. Jpn J Nutr. 44, 307, 1986.

24. KHADRI A., SERRALHEIRO M.L.M., NOGUEIRA J.M.F., NEFFATI M., SMITI S., ARAÚJO M.E.M. Antioxidant and antiacetylcholinesterase activities of essential oils from Cymbopogon schoenanthus L. Spreng. Determination of chemical composition by GC-mass spectrometry and 13C NMR. Food Chem. 109, 630, 2008.

25. GULLÉN M.D., RUIZ A. High resolution ${ }^{1} \mathrm{H}$ nuclear magnetic resonance in the study of edible oils and fats. Trends Food Sci Technol. 328, 2001.

26. STATSOFT. STATISTICA for Windows (Computer program Electronic Manual). StatSoft Inc,Tulsa, Ok, 1998.

27. OUHIBI C., ATTIA H., REBAH F., MSILINI N., CHEBBI M., AARROUF J., URBAN L., LACHAAL M. Salt stress mitigation by seed priming with UV-C in lettuce plants: Growth, antioxidant activity and phenolic compounds. Plant Physiol Biochem. 1, 2014.

28. TARCHOUNE I., DEGL'INNOCENTI E., KADDOUR R., GUIDI L., LACHAÂL M., NAVARI-IZZO F., OUERGHI Z. Effects of $\mathrm{NaCl}$ or $\mathrm{Na}_{2} \mathrm{SO}_{4}$ salinity on plant growth, ion content and photosynthetic activity in Ocimum basilicum L. Acta Physiol Plant. 34, 607, 2012.

29. PARIDA A.K., DAS A.B., SANADA Y., MOHANTY P. Effects of salinity on biochemical components of the mangrove, Aeceras corniculatum. Aquatic Bot. 80, 77, 2004.

30. BEN TAÂRIT M., MSAADA K., HOSNI K., MARZOUK B. Changes in fatty acid and essential oil composition of sage (Salvia officinalis L.) leaves under $\mathrm{NaCl}$ stress. Food Chem. 119, 951, 2012a.

31. BEN TAÂRIT M., MSAADA K., HOSNI K., MARZOUK B. Fatty acids, phenolic changes and antioxidant activity of clary sage (Salvia sclarea L.) rosette leaves grown under saline conditions. Ind Crops Prod. 38, 58, 2012b.

32. HARRATHI J., ATTIA H., NEFFATI M., HOSNI K., MARZOUK B., LACHÂAL M., KARRAY-BOURAOUI N. Salt effects on shoot growth and essential oil yield and composition in safflower (Carthamus tinctorius L.). J Essent Oil Res. 25 (6), 482, 2013.

33. ASSAHA D.V.M., UEDA A., SANEOKA H. Comparison of growth and mineral accumulation of two solanaceous species, Solanum scabrum Mill. (huckleberry) and S. melongena L. (eggplant), under salinity stress. Soil Sci. Plant Nutr. 59, 912, 2013.

34. DOGANLAR Z.B., DEMIR K., BASAK H., GUL I. Effects of salt stress on pigment and total soluble protein contents of three different tomato cultivars. Afr. J. Agric. Res. 5, 2056, 2010.

35. MANUCHEHRI R., SALEHI H. Physiological and biochemical changes of common bermudagrass (Cynodon dactylon [L.] Pers.) under combined salinity and deficit irrigation stresses. IS. Afr. J. Bot. 92, 83, 2014.

36. MAHMOUDI H., KADDOUR R., HUANG J., NASRI N., OLFA B., M'RAH S., HANNOUFA A., LACHAÂL M., OUERGHI Z. Varied tolerance to $\mathrm{NaCl}$ salinity is related to biochemical changes in two contrasting lettuce genotypes. Acta Physiol Plant. 33, 1613, 2012. doi:10.1007/s11738010-0696-2.

37. MANAA A., GHARBI E., MIMOUNI H., WASTI S., ASCHI-SMITI S., LUTTS S., BEN AHMED H. Simultaneous application of salicylic acid and calcium improves salt tolerance in two contrasting tomato (Solanum lycopersicum) cultivars. S. Afr. J. Bot. 95, 32, 2014.

38. ALHASNAWI A.N., CHE RADZIAH C.M.Z., KADHIMI A.A., ISAHAK A., MOHAMAD A., YUSOFF W.M.W. Enhancement of antioxidant enzymes activities in rice callus by ascorbic acid under salinity stress. Biol. Plant. XX (X), XXX, 2016.

39. BEN ABDALLAH S., AUNG B., AMYOT L., LACHAÂL M., KARRAY-BOURAOUI N., HANNOUFA A. Salt stress $(\mathrm{NaCl})$ affects plant growth and branch pathways of carotenoid and flavonoid biosyntheses in Solanum nigrum. Acta Physiol Plant. 38, 72, 2016.

40. KNÖSS W, ZAPP J. Accumulation of Furanic Labdane Diterpenes in Marrubium vulgare and Leonurus cardiac. Planta Med. 64, 316, 1998.

41. BEN TAÂRIT M., MSAADA K., HOSNI K., MARZOUK B. Physiological changes and essential oil composition of clary sage (Salvia sclarea L.) rosette leaves as affected by salinity. Acta Physiol Plant. 33 (1), 153, 2011.

42. ZERBE P., CHIANG A., DULLAT H., O'NEIL-JOHNSON M., STARKS C., HAMBERGER B., BOHLMANN J. Diterpene synthases of the biosynthetic system of medicinally active diterpenoids in Marrubium vulgare. The Plant J. 79, 914, 2014.

43. PATERAKI I., KANELLIS A.K. Stress and developmental responses of terpenoid biosynthetic genes in Cistus creticus subsp. Plant Cell Rep. 29 (6), 629, 2010.

44. NEFFATI M., SRITI J., HAMDAOUI G., KCHOUK E.M., MARZOUK B. Salinity impact on fruit yield, essential oil composition and antioxidant activities of Coriandrum sativum fruit extracts. Food Chem. 124, 221, 2011.

45. SALEH A.M., MADANY M.M.Y. Coumarin pretreatment alleviates salinity stress in wheat seedlings. Plant Physiol Biochem. 88, 27, 2015.

46. TIWARI J.K., MUNSHI A.D., KUMAR R., PANDEY R.N., ARORA A., BHAT J.S., SUREJA K. Effect of salt stress on cucumber: $\mathrm{Na}+-\mathrm{K}+$ ratio, osmolyte concentration, phenols and chlorophyll content. Acta Physiol Plant. 32 (1),103, 2010.

47. KARRAY-BOURAOUI N., HARBAOUI F., RABHI M., JALLALI I., KSOURI R., ATTIA H., MSILINI N., LACHAAL M. Different antioxidant responses to salt stress in two different provenances of Carthamus tinctorius L. Acta Physiol Plant. 33, 2011.

48. BEN ABDALLAH S., RABHI M., HARBAOUI F., ZARKALAI F., LACHÂAL M., KARRAY-BOURAOUI N. Distribution of phenolic compounds and antioxidant activity between young and old leaves of Carthamus tinctorius L. and their induction by salt stress. Acta Physiol Plant. 35(4), 1161, 2013. 
49. BAÂTOUR O., KADDOUR R., TARCHOUN I., NASRI N., MAHMOUDI H., ZAGHDOUDI M., GHAITH H., MARZOUK B., BEN NASRI-AYACHI M., LACHAÂL M. Modification of Fatty Acid, Essential Oil and Phenolic Contents of Salt-Treated Sweet Marjoram (Origanum majorana L.) According to Developmental Stage. J. Food Sci. 77 (10), 1054, 2010.

50. REZAZADEH A., GHASEMEZHAD A., BARANI M., TELMADARREHEI T. Effect of salinity on phenolic composition and antioxidant activity of Artichoke (Cynara scolymus L.) leaves. J. Med. Plants Res. 6 (3), 245, 2012.

51. GOUPY P., HUGUES M., BOIVIN P., AMIOT J.M. “Antioxidant composition and activity of barley (Hordeum vulgare) and malt extracts and of isolated phenolic compounds," J. Sci. Food Agr. 79, 1625, 1999.
52. GILL S.S., TUTEJA N. Reactive oxygen species and antioxidant machinery in abiotic stress tolerance in crop plants. Plant Physiol Biochem. 48, 909, 2010.

53. VELIOGLU Y.S., MAZZA G., GAO L., OOMAH B.D. Antioxidant activity and total phenolics in selected fruits, vegetables, and grain products. J. Agric. Food Chem. 46, 4113, 1998.

54. FRANKEL E.N., HUANG S.W., KANNER J., GERMAN J.B. Interfacial phenomena in the evaluation of antioxidants: Bulk oils vs emulsion. J. Agric. Food Chem. 42, 1054, 1994.

55. BASYUNI M., BABA S., INAFUKU M., IWASKI H., KINJO K., OKU H. Expression of terpenoid synthase mRNA and terpenoid content in salt stressed mangrove. J Plant Physiol. 166, 1786, 1999. 
